\title{
THE NAGSSUGTOQIDIAN BOUNDARY AND THE DEFORMATION OF THE KÂNGAMIUT DYKE SWARM IN THE SØNDRE STRØMFJORD AREA
}

\section{A. Escher, J. Escher and J. Watterson}

The season's objective was the reconnaissance mapping of a $c .7000 \mathrm{~km}^{2}$ area lying between Søndre Strømfjord, the Inland Ice and the Sukkertoppen ice cap. An important feature of this region was known to be the progressive northward deformation of the Kangâmiut dyke swarm and an associated amphibolite facies metamorphism of both the dykes and their granulite facies country rocks (Noe-Nygaard \& Ramberg, 1961). These changes have been regarded as marking the southern limit of Nagssugtoqidian orogenic activity. In order to make a more comprehensive study of this boundary, the reconnaissance was extended to include the $c .3000 \mathrm{~km}^{2}$ area southwest of the Sukkertoppen ice cap, bounded by Søndre Strømfjord and Evigheds Fjord.

The geological reconnaissance showed that, contrary to previous theories, the Nagssugtoqidian boundary has an approximately NE-SW strike.

H. P. Zeck of the Petrological Institute, Copenhagen, studied and sampled extensively the border zone between granulite facies rocks and amphibolite facies rocks in order to make a detailed petrological study of the metamorphic changes.

R. Chessex of the Institut de Minéralogie, Geneva, sampled all the major rocktypes north and south of the Nagssugtoqidian boundary with a view to zircon age studies.

Area south of the Nagssugtoqidian boundary

This area is characterised by quartz-bearing granulite facies gneisses, in which banding and foliation are often indistinct or absent. Layers of basic agmatites are persistent in many places. Rapakivi-type granites occur as massifs within the gneisses on the eastern border of the area.

In the inner part of Evigheds Fjord the granulite facies gneisses are retrogressed in large zones of intense flattening and shearing. Pseudotachylite breccias and veins are common in the most intensively deformed zones. Similarly retrogressed rocks are found in the southern part of Angujârtorfiup nunâ. 
The Kangâmiut dyke swarm post-dates the events described above. A traverse of $105 \mathrm{~km}$ was made across the strike $\left(020^{\circ}-025^{\circ}\right)$ of the swarm and showed the presence of more than 100 dykes over $15 \mathrm{~m}$ in width. Most of the dykes are fresh dolerites; a small proportion are composite with centres of leucogabbro. Dykes with centres of foliated garnet amphibolite similar to those in the Sukkertoppen district (Windley, in press) are restricted to the retrogressive shear zones and may be the result of renewed movements.

The Kangâmiut dykes cut an earlier and less dense swarm of macroscopically similar dykes, striking $c .090^{\circ}$. The existense of two distinct dyke directions is of great assistance in studying the Nagssugtoqidian deformation.

The Nagssugtoqidian boundary

This boundary cuts across Søndre Strømfjord near the Sukkertoppen ice cap, and then south of the fjord turns towards the NE, in a direction roughly parallel to the fjord. It forms a zone approximately $5 \mathrm{~km}$ wide in which retrogression of the granulite facies gneisses takes place. The mineralogical changes are closely correlated with structural changes, the most dramatic of which is a change in strike of both dyke swarms. This change can be abrupt or more gradual and brought about in a series of parallel shear zones. The Kangâmiut dykes show a clockwise and the E-W dykes an anticlockwise reorientation. This implies that the deformation is mainly due to a rotational or shear strain, the principal strain direction being at right angles with the strike of the Nagssugtoqidian boundary. The foliation of the gneisses is also reoriented and partly transposed by the Nagssugtoqidian shear deformation.

\section{Area north of the Nagssugtoqidian boundary}

In this area the gneiss foliation and the dykes are in most places concordant. Locally, however, the deformation must have been less pronounced and the dykes are clearly discordant to the gneiss foliation.

The northern limit of the reoriented Kangâmiut swarm lies about $30 \mathrm{~km}$ north of Sondrestrom Airbase. The width of the swarm here, measured normal to the plane of the reoriented dykes, is $c .20 \mathrm{~km}$, i. e. about $20 \%$ of the original width.

Amphibolite facies rocks continue only $20 \mathrm{~km}$ northwards from Sondrestrom Airbase after which both dykes and gneisses have granulite facies assemblages of Nagssugtoqidian age. The metamorphic boundary is here represented by an important thrust zone dipping to the NW.

\section{Supracrustal rocks}

Identifiable supracrustal rocks occupy only a few $\mathrm{km}^{2}$ at two separate localities, both north of the Nagssugtoqidian boundary. The south-western locality is made of anthophyllite schists, phyllites and probably pillow lavas, while the north-eastern one contains marbles and phyllites. Both occurrences are clearly cut by the Kangâmiut dykes and must therefore be of pre-Nagssugtoqidian age. 
Ultrabasic dykes and veins

Post-dating all tectonic events are numerous ultrabasic dykes and veins up to $3 \mathrm{~m}$ in width, striking NW-SE or NE-SW. Many of these intrusions contain abundant rounded nodules and rounded xenocrysts of olivine or biotite. The rocks collected from this diatreme suite may include kimberlites.

\section{References}

Noe-Nygaard, A. \& Ramberg, H. 1961 : Geological reconnaissance map of the country between latitudes $69^{\circ} \mathrm{N}$ and $63^{\circ} 45 \mathrm{~N}$, West Greenland. Meddr Gronland 123, 5.

Windley, B. F. in press: Primary quartz ferro-dolerite/garnet amphibolite dykes in the Sukkertoppen region of West Greenland. Geol. $J$.

\section{QUATERNARY DEPOSITS BETWEEN THE SUKKERTOPPEN ICE CAP AND NORDRE STRØMFJORD}

\section{A. Weidick and N. W. Ten Brink}

The area investigated during 1969 is located approximately between $66^{\circ} 10^{\prime}$ and $67^{\circ} 30^{\prime} \mathrm{N}$, and $50^{\circ}$ and $52^{\circ} \mathrm{W}$, the eastern half of the West Greenland ice-free land area transected by Søndre Strømfjord. The principal objectives of the work were to map and describe the glacial and emerged marine deposits for a Quaternary map at 1:500 000 scale, and to collect material for establishing a radiometric chronology of former ice-margin positions and sea levels. In order to study as large an area as possible, the investigations north of Søndre Strømfjord and Sondrestrom Airbase were conducted by A. Weidick, the area south of this by N. W. Ten Brink.

The altitudes in the area decrease from the south (summits approximately 1300 $1500 \mathrm{~m}$ ) to the north (summits approximately $600 \mathrm{~m}$ ). The area is limited to the east by the present Inland Ice, to the south and west by the highlands of the Sukkertoppen and coastal Holsteinsborg districts, whereas to the north it extends into the lowlands around the inner branches of Nordre Strømfjord with maximum elevations rarely above $500 \mathrm{~m}$.

The present climatic conditions are extremely continental; the mean temperature at Sondrestrom Airbase for January is $-16^{\circ} \mathrm{C}$, for July $+10^{\circ} \mathrm{C}$, and for the year $-4.4^{\circ} \mathrm{C}$, with annual precipitation equal to $13-20 \mathrm{~cm}$ water equivalent. The existence of continuous permafrost throughout the area is therefore anticipated, and the results of various frost-action processes including patterned ground features are commonly 